\title{
AKTIVITAS ANTIMIKROBA DAN ANTIOKSIDAN EKSTRAK BEBERAPA BAGIAN TANAMAN KUNYIT (Curcuma longa)
}

\author{
Eris Septiana ${ }^{1}$, Partomuan Simanjuntak ${ }^{1,2}$ \\ ${ }^{1)}$ Pusat Penelitian Bioteknologi-LIPI Bogor \\ ${ }^{2)}$ Fakultas Farmasi Universitas Pancasila \\ Email:septiana.eris@gmail.com
}

\begin{abstract}
ABSTRAK
Kunyit (Curcuma longa) merupakan tanaman obat tradisional yang biasa digunakan sebagai bumbu masakan dan sebagai bahan obat meliputi antimikroba, antioksidan, antitumor, dan anti inflamasi. Tujuan dari penelitian ini ialah untuk mengetahui aktivitas antimikroba dan antioksidan dari beberapa organ tanaman kunyit meliputi akar, rimpang, batang, dan daun. Semua bagian diekstraksi dengan etanol dan etil asetat. Seluruh ekstrak etanol dan etil asetat diuji aktivitas antimikrobanya menggunakan metode difusi cakram kertas terhadap Escherichia coli, Staphylococcus aureus, dan Candida albicans. Kloramfenikol dan nistatin masing-masing digunakan sebagai kontrol positif untuk uji antibakteri dan antijamur, sedangkan masing-masing pelarut untuk ekstraksi juga digunakan sebagai kontrol negatif. Aktivitas antioksidan dilakukan menggunakan metode 1,1-difenil-2pikril hidrazil (DPPH) dan asam askorbat digunakan sebagai standar. Hasil aktivitas antimikroba menunjukkan bahwa ekstrak etil asetat dari daun dan batang memiliki aktivitas penghambatan tertinggi terhadap $S$. aureus, ekstrak etil asetat dari akar dan batang memiliki aktivitas penghambatan tertinggi terhadap E. coli, dan ekstrak etil asetat dari daun memiliki aktivitas penghambatan tertinggi terhadap $C$. albicans. Ekstrak etil asetat dari rimpang memiliki aktivitas antioksidan tertinggi diantara ekstrak lainnya.
\end{abstract}

Kata kunci: Antimikroba, antioksidan, Curcuma longa, difusi cakram kertas, DPPH

\section{ANTIMICROBIAL AND ANTIOXIDANT ACTIVITIES VARIOUS PARTS OF TURMERIC (Curcuma longa) PLANT EXTRACT}

\begin{abstract}
Turmeric (Curcuma longa) is a traditional medicinal plant that commonly used as a spice and medicinal properties including antimicrobial, antioxidant, antitumor, and antiinflammatory activity. The aims of this study were to determine antimicrobial and antioxidant activity of roots, rhizomes, stems, and leaves of turmeric plant. All parts were extracted with ethanol and ethyl acetate. The disc diffusion method was used to antimicrobial activity against Escherichia coli, Staphylococcus aureus, and Candida albicans. The chloramphenicol and nystatin antibiotics were used as positive control for antibacterial and antifungal assay respectively, while solvents for extraction were used as negative control. The antioxidant activity was conducted using 1,1-diphenyl-2-picryl hydrazyl (DPPH) method with ascorbic acid used as the standard. The ethyl acetate extracts of leaves and stems showed the best antibacterial activity against $S$. aureus, while the ethyl acetate extracts of roots and stems showed the best antibacterial activity against E. coli. The ethyl acetate extracts of leaves showed the best antifungal activity against $C$. albicans. The ethyl acetate extract of rhizomes showed the highest antioxidant activity.
\end{abstract}

Key words: Antimicrobial, antioxidant, Curcuma longa, disc diffusion method, DPPH 


\section{PENDAHULUAN}

Kunyit (Curcuma longa) merupakan tanaman golongan temu-temuan yang banyak dimanfaatkan sebagai bumbu masakan maupun pewarna makanan. Selain itu, tanaman kunyit juga sering digunakan sebagai tanaman obat tradisional untuk mengobati beberapa jenis penyakit seperti demam, diare, lever, sesak nafas, radang hidung, maag, eksim, dan hipertensi. Manfaat kunyit sebagai obat tradisional mendorong para peneliti untuk terus menemukan manfaat lain dari tanaman kunyit. Beberapa manfaat kunyit yang telah dilaporkan secara ilmiah ialah sebagai antimikroba dan antioksidan.

Ekstrak petroleum eter, kloroform, metanol dan air dari rimpang kunyit mempunyai aktivitas antimikroba terhadap bakteri seperti Escherichia coli, Salmonella enteriditis, Clostridium perfringens, Staphylococcus aureus, Campylobacter jejuni, Bacillus cereus, serta beberapa fungi seperti Saccharomyces cerevisiae, Hansenula anomala, Mucor mucedo, dan Candida albicans (Sunilson et al., 2009). Selain bagian rimpang, bagian daun tanaman kunyit juga memiliki aktivitas antimikroba. Pada umumnya bagian daun diekstrak untuk mendapatkan minyaknya. Ekstrak minyak yang berasal daun tanaman kunyit mampu menghambat pertumbuhan beberapa jenis bakteri Gram negatif dan positif serta fungi (Parveen et al., 2013). Sehingga dapat dikatakan bahwa rimpang dan daun kunyit mempunyai aktivitas antimikroba spektrum luas yang meliputi bakteri Gram negatif dan positif serta fungi.

Selain memiliki kemampuan sebagai antimikroba, kunyit memiliki kemampuan sebagai antioksidan. Kemampuan sebagai antioksidan dari rimpang kunyit telah banyak dilaporkan oleh para peneliti. Beberapa diantaranya ialah ekstrak etanol rimpang kunyit mempunyai aktivitas antioksidan dengan menggunakan metode peredaman radikal bebas. Lebih lanjut dari penelitian tersebut menunjukkan bahwa ekstrak etanol rimpang kunyit memiliki aktivitas antioksidan yang paling tinggi dibandingkan dengan empat jenis Curcuma lainnya yaitu C. zedoaria, C. angustifolia, C. aromatica, dan C. amada (Nahak \& Sahu, 2012). Selain bagian rimpang, bagian daun tanaman kunyit juga telah dilaporkan memiliki kemampuan sebagai antioksidan. Ekstrak metanol daun kunyit segar dan serbuk daun kunyit memiliki aktivitas antioksidan (Yan \& Asmah, 2010).

Tanaman kunyit sendiri terdiri atas bagian-bagian vegetatif dan generatif selama siklus hidupnya. Bagian vegetatif diantaranya ialah daun, batang pendek yang merupakan pangkal munculnya tangkai daun di bagian atas dan juga pada pangkal nya muncul rimpang di bagian bawah. Rimpang merupakan modifikasi dari batang serta bagian akar serabut yang muncul dari batang. Sedangkan bagian generatifnya yaitu bunga yang muncul diantara tangkai daun. Namun tidak semua tanaman kunyit menghasilkan bunga pada satu kali siklus hidupnya.

Penelitian tentang kunyit saat ini lebih banyak terfokus pada bagian rimpang dan daun saja, padahal bagian tanaman kunyit lainnya seperti bunga juga dapat dimanfaatkan secara tradisional. Daun kunyit biasa digunakan sebagai penyedap pada beberapa masakan. Sedangkan bagian bunganya dapat dijadikan lalapan. Penelitian yang telah dilakukan masih terbatas pada bagian rimpang dan daun tanaman kunyit, sedangkan bagian tanaman kunyit yang lain seperti akar dan batang belum dilakukan. Oleh karena itu penelitian ini bertujuan untuk mengetahui kemampuan antimikroba dan antioksidan seluruh bagian fase vegetatif tanaman kunyit yang meliputi akar, rimpang, batang, dan daun sehingga diharapkan di masa depan dapat dikembangkan menjadi antibiotika alami dan agen antioksidan baru yang berasal dari tanaman kunyit selain dari bagian rimpang dan daun yang telah umum dimanfaatkan.

\section{METODE PENELITIAN}

Penelitian ini dilaksanakan pada bulan September 2014 - Februari 2015 
bertempat di Laboratorium Kimia Bahan Alam, Puslit Bioteknologi LIPI.

\section{Bahan}

Bahan hidup berupa tanaman kunyit diperoleh dari daerah Cibinong, Bogor, Jawa Barat yang kemudian dideterminasi di Herbarium Bogoriense, Puslit Biologi LIPI sebagai Curcuma longa, isolat bakteri Escherichia coli dan Staphylococcus aureus, serta fungi Candida albicans yang merupakan isolat koleksi Laboratorium Kimia Bahan Alam, Puslit Bioteknologi LIPI.

Bahan kimia yang digunakan meliputi etanol, etil asetat, kloroform, metanol p.a, $\mathrm{NH}_{4} \mathrm{OH} 25 \%, \mathrm{HCl}$, amil alkohol, eter, asam asetat glasial, asam sulfat pekat, pereaksi Dragendorff, DPPH, asam askorbat, kloramfenikol, nistatin dan media pertumbuhan mikroba Nutrient Broth (NB), Potato Dextrose Broth (PDB), Nutrient Agar (NA), Potato Dextrose Agar (PDA).

\section{Alat}

Penguap hampa putar, pemutar goyang, spektrofotometer UV-Vis, cawan petri, neraca analitik, dan pipet mikro.

\section{Cara Kerja \\ Ekstraksi}

Sebagian sampel kunyit dikirim ke Herbarium Bogoriense, Puslit Biologi LIPI, Cibinong untuk dideterminasi. Sampel tanaman kunyit lainnya kemudian dipisahkan berdasarkan bagian-bagian fase vegetatifnya meliputi akar, rimpang, batang, dan daun. Masing-masing bagian kemudian dipotong kecil-kecil, dijemur di bawah sinar matahari hingga kering. Sampel yang telah kering kemudian ditimbang masing-masing sebanyak $25 \mathrm{~g}$ dan dimaserasi dengan etanol $(250 \mathrm{~mL})$ dan etil asetat $(250 \mathrm{~mL})$ sebanyak lima kali secara terpisah. Hasil maserasi kemudian disaring dan dipekatkan hingga didapatkan ekstrak kasar etanol dan etil asetat masing-masing bagian tanaman kunyit.

\section{Uji Antimikroba}

Uji aktivitas antimikroba dilakukan dengan metode difusi cakram kertas (Baydar et al., 2004). Konsentrasi ekstrak yang digunakan ialah 10.000, 15.000, dan 20.000 ppm. Kontrol positif kloramfenikol 100 ppm untuk bakteri dan nistatin 100 ppm untuk fungi dan kontrol negatif berupa pelarut ekstrak. Cawan Petri kemudian diinkubasi pada suhu $37^{\circ} \mathrm{C}$ untuk bakteri dan $30^{\circ} \mathrm{C}$ untuk fungi selama 24 jam dan zona bening yang terbentuk di sekitar cakram kertas kemudian diukur.

\section{Uji Aktivitas Antioksidan}

Uji aktivitas antioksidan dilakukan dengan metode peredaman radikal bebas dengan menggunakan senyawa DPPH $(1,1-$ diphenyl-2-picryl hydrazyl) (Tiwari et al., 2006) dengan modifikasi pada panjang gelombang dari $515 \mathrm{~nm}$ mejadi $517 \mathrm{~nm}$. Konsentrasi larutan uji sebesar 5, 10, 25, 50, dan 100 ppm, asam askorbat sebagai pembanding sebesar 3, 6, 9, 12, dan $15 \mathrm{ppm}$, serta DPPH blanko 0,04 mM. Seluruh sampel larutan uji, blanko dan asam askorbat diinkubasi pada suhu $37^{\circ} \mathrm{C}$ selama 30 menit. Serapan seluruh sampel kemudian diukur pada panjang gelombang $517 \mathrm{~nm}$. Aktivitas antioksidan dinyatakan dalam persen inhibisi menggunakan persamaan:

$\%$ inhibisi $=\frac{\text { serapan blanko }- \text { serapan sampel }}{\text { serapanblanko }} \times 100 \%$

Nilai $\mathrm{IC}_{50}$ diperoleh dari analisis probit menggunakan program SPSS.

\section{Uji Penapisan Fitokimia}

Uji penapisan fitokimia (Fransworth, 1966) meliputi uji alkaloid, flavonoid dan steroid/triterpenoid. Uji alkaloid dilakukan dengan melembabkan sampel dengan $\mathrm{NH}_{4} \mathrm{OH} 25 \%$ dan kloroform. Filtrat berupa larutan organik diekstraksi dengan $\mathrm{HCl}$ pekat. Lapisan asam kemudian ditambah beberapa tetes pereaksi Dragendorff. Terbentuknya endapan merah bata dengan pereaksi Dragendorff menunjukkan adanya alkaloid. Pada uji flavonoid, sampel dididihkan dalam air selama lima menit lalu disaring. Filtrat yang terbenetuk 
ditambahkan dengan serbuk magnesium, $\mathrm{HCl}$ pekat dan amil alkohol, dikocok dan dibiarkan memisah. Adanya senyawa flavonoid ditunjukkan dengan terbentuknya warna merah, kuning atau jingga pada lapisan alkohol. Pada uji senyawa steroid/triterpenoid, sampel dimaserasi dengan eter, lalu disaring. Filtrat kemudian diuapkan dalam cawan penguap. Ke dalam residu ditambahkan asam asetat glasial dan 1 tetes asam sulfat pekat. Terbentuknya warna merah, hijau ungu dan akhirnya biru menunjukkan adanya senyawa steroid/ triterpenoid.

\section{HASIL DAN PEMBAHASAN Ekstraksi}

Rendemen ekstrak simplisia daun kunyit mempunyai persentase yang paling besar dibanding simplisia bagian tanaman kunyit lainnya baik yang diekstraksi dengan pelarut etanol maupun etil asetat masingmasing sebesar 26,8 dan 6,04\%. Sedangkan persentase rendemen terendah terdapat pada ekstrak etil asetat dan etanol bagian batang tanaman kunyit yaitu masing-masing sebesar 0,44 dan $4,6 \%$ (Tabel 1 ).

Tabel 1. Rendemen Ekstrak Simplisia Akar, Rimpang, Batang dan Daun Kunyit

\begin{tabular}{lcccc}
\hline \multicolumn{1}{c}{$\begin{array}{c}\text { Simplisia Bagian } \\
\text { Tanaman Kunyit }\end{array}$} & \multicolumn{2}{c}{ Ekstrak Etil Asetat } & \multicolumn{2}{c}{ Ekstrak Etanol } \\
Bobot $(\mathbf{g})$ & $\mathbf{\%}$ b/b & Bobot $(\mathbf{g})$ & $\mathbf{\%}$ b/b \\
\hline Akar & 0,57 & 2,28 & 2,24 & 8,96 \\
Rimpang & 0,33 & 1,32 & 1,94 & 7,76 \\
Batang & 0,11 & 0,44 & 1,15 & 4,6 \\
Daun & 1,51 & 6,04 & 6,7 & 26,8 \\
\hline
\end{tabular}

\section{Uji Aktivitas Antimikroba}

Ekstrak etil asetat seluruh bagian tanaman kunyit mempunyai aktivitas penghambatan terhadap semua mikroba uji. Ekstrak etanol semua bagian tanaman kunyit tidak memiliki aktivitas penghambatan terhadap C. albicans, sedangkan ekstrak etanol daun kunyit tidak memiliki aktivitas penghambatan terhadap seluruh mikroba uji (Tabel 2). Terdapat hubungan yang searah antara konsentrasi ekstrak dengan diameter zona hambat, dimana semakin tinggi konsentrasi ekstrak, diameter daya hambat yang terbentuk akan semakin besar.

Selain itu, terdapat hal yang menarik dari hasil uji antimikroba, dimana pada ekstrak etil asetat rimpang memiliki aktivitas antimikroba yang masih dibawah semua ekstrak bagian tanaman kunyit lainnya. Walaupun demikian, ekstrak etanol rimpang memiliki aktivitas antimikroba yang paling tinggi diantara ekstrak etanol bagian tanaman kunyit lainnya. Untuk ekstrak etil asetat, ekstrak daun dan batang kunyit lebih efektif dalam menghambat pertumbuhan bakteri Gram positif $S$. aureus, sedangkan ekstrak rimpang dan akar lebih efektif terhadap bakteri Gram negatif E. coli.
Untuk ekstrak etanol, ekstrak batang dan rimpang lebih efektif dalam menghambat pertumbuhan bakteri Gram negatif E. coli, sedangkan ekstrak akar lebih efektif terhadap bakteri Gram positif $S$. aureus. Ekstrak etanol dan etil asetat seluruh bagian vegetatif tanaman kunyit memiliki aktivitas antimikroba. Hal ini sejalan dengan penelitian sebelumnya yang melaporkan bahwa ekstrak etanol rimpang dan daun serta ekstrak etil asetat rimpang tanaman kunyit memiliki aktivitas antimikroba (Arutselvi et al., 2012; Asimi et al., 2013). Ekstrak etil asetat cenderung memiliki aktivitas antimikroba terhadap mikroba uji yang lebih baik dibandingkan dengan ekstrak etanol. Fratianni et al. (2013) melaporkan bahwa ekstrak etil asetat dari tanaman Hypericum connatum memiliki aktivitas antimikroba yang lebih baik terhadap bakteri $S$. aureus dan $E$. coli dibandingkan dengan ekstrak etanol.

Ekstrak etil asetat dan etanol setiap bagian tanaman kunyit cenderung mempunyai kemampuan antibakteri yang lebih besar dibanding dengan kemampuan antifungi. Hasil ini sejalan dengan penelitian Pattaratanawadee et al. (2006) yang juga 
telah melaporkan bahwa ekstrak etanol rimpang kunyit lebih efektif dalam menghambat bakteri penyebab kebusukan dibandingkan dengan fungi. Demikian pula dengan kemampuan dalam menghambat pertumbuhan bakteri, seluruh ekstrak lebih mampu menghambat pertumbuhan $S$. aureus yang merupakan bakteri Gram positif dibandingkan dengan E. coli yang merupakan bakteri Gram negatif. Hasil serupa juga didapatkan pada penelitian Schelz et al. (2010) yang melaporkan bakteri Gram negatif lebih resisten terhadap minyak atsiri dari tanaman rempah. Hal ini karena struktur dinding sel bakteri Gram negatif lebih kompleks dibandingkan dengan Gram positif (Antunes et al., 2012). Dinding sel bakteri Gram negatif memiliki konsentrasi lipid yang tinggi sebagai lapisan penghalang yang membuat bakteri ini lebih resisten terhadap senyawa kimia yang memiliki daya difusi rendah (Hanouda \& Baker, 2000). Sedangkan pada bakteri Gram positif, senyawa antibakteri lebih mudah melintasi dinding sel karena hanya mengandung peptidoglikan dan membran luar yang lebih tipis (Lambert et al., 2001).

Tabel 2. Aktivitas antimikroba dari ekstrak etanol dan etil asetat seluruh bagian tanaman kunyit

\begin{tabular}{|c|c|c|c|c|}
\hline \multirow{2}{*}{ Ekstrak } & \multirow{2}{*}{$\begin{array}{l}\text { Konsentrasi } \\
(\mathbf{p p m})\end{array}$} & \multicolumn{3}{|c|}{ Diameter penghambatan (mm) } \\
\hline & & E. coli & S. aureus & C. albicans \\
\hline \multirow{3}{*}{ Daun etil asetat } & 10.000 & 6 & 13 & 8 \\
\hline & 15.000 & 8 & 14 & 10 \\
\hline & 20.000 & 10 & 16 & 12 \\
\hline \multirow{3}{*}{ Daun etanol } & 10.000 & - & - & - \\
\hline & 15.000 & - & - & - \\
\hline & 20.000 & - & - & - \\
\hline \multirow{3}{*}{ Batang etil asetat } & 10.000 & 8 & 12 & 4 \\
\hline & 15.000 & 10 & 14 & 7 \\
\hline & 20.000 & 12 & 16 & 10 \\
\hline \multirow{3}{*}{ Batang etanol } & 10.000 & 5 & 3 & - \\
\hline & 15.000 & 6 & 4 & - \\
\hline & 20.000 & 7 & 5 & - \\
\hline \multirow{3}{*}{ Rimpang etil asetat } & 10.000 & 5 & 6 & 2 \\
\hline & 15.000 & 7 & 7 & 3 \\
\hline & 20.000 & 9 & 8 & 4 \\
\hline \multirow{3}{*}{ Rimpang etanol } & 10.000 & 7 & 6 & - \\
\hline & 15.000 & 8 & 7 & - \\
\hline & 20.000 & 9 & 8 & - \\
\hline \multirow{3}{*}{ Akar etil asetat } & 10.000 & 7 & 6 & 1 \\
\hline & 15.000 & 10 & 9 & 3 \\
\hline & 20.000 & 12 & 12 & 4 \\
\hline \multirow{3}{*}{ Akar etanol } & 10.000 & 3 & 5 & - \\
\hline & 15.000 & 4 & 6 & - \\
\hline & 20.000 & 6 & 7 & - \\
\hline Nistatin & 100 & - & - & 14 \\
\hline Kloramfenikol & 100 & 14 & 17 & - \\
\hline Etil asetat & & - & - & - \\
\hline Etanol & & - & - & - \\
\hline
\end{tabular}


Pada penelitian sebelumnya tentang aktivitas antimikroba bagian tanaman kunyit, masih sebatas pada bagian rimpang dan daunnya saja. Ekstrak rimpang kunyit mampu menghambat pertumbuhan bakteri dan fungi (Sunilson et al., 2009). Demikian pula ekstrak daun kunyit mampu menghambat pertumbuhan beberapa galur bakteri (Mazumder et al., 2000). Aktivitas antimikroba dari tanaman yang biasa dijadikan bumbu masakan yang umum digunakan seperti kunyit dapat dijadikan acuan dalam penggunaannya seperti pengawetan bahan mentah maupun olahan, farmasetikal, pengobatan alternatif dan terapi alami (Lis-Balcin \& Deans, 1997). Kemampuan antimikroba dari ekstrak tanaman kunyit dapat juga dijadikan sebagai pengawet alami dalam mencegah kerusakan makanan akibat aktivitas mikroba (Panpatil et al., 2013).

\section{Uji Aktivitas Antioksidan}

Hasil pengujian aktivitas antioksidan menunjukkan bahwa seluruh ekstrak bagian tanaman kunyit memiliki aktivitas antioksidan (Tabel 3). Hasil uji aktivitas antioksidan juga menunjukkan bahwa ekstrak etil asetat rimpang kunyit menghasilkan aktivitas antioksidan terbaik dengan IC $_{50}$ sebesar 20,42 ppm. Secara keseluruhan, aktivitas antioksidan sampel masih sangat jauh dibawah kontrol positif yaitu vitamin $\mathrm{C}$ (asam askorbat) yang memiliki nilai $\mathrm{IC}_{50}$ sebesar 3,99 ppm.

Tabel 3. Aktivitas antioksidan dari ekstrak etanol dan etil asetat seluruh bagian tanaman kunyit

\begin{tabular}{|c|c|c|c|c|c|}
\hline \multirow{2}{*}{$\begin{array}{c}\text { Simplisia bagian } \\
\text { tanaman kunyit }\end{array}$} & \multirow{2}{*}{$\begin{array}{c}\text { Konsentrasi } \\
\text { (ppm) }\end{array}$} & \multicolumn{2}{|c|}{ Ekstrak etanol } & \multicolumn{2}{|c|}{ Ekstrak etil asetat } \\
\hline & & Inhibisi (\%) & $\mathrm{IC}_{50}$ & Inhibisi (\%) & $\mathrm{IC}_{50}$ \\
\hline \multirow{5}{*}{ Akar } & 5 & 8,29 & \multirow{5}{*}{$31,79 \mathrm{ppm}$} & 8,54 & \\
\hline & 10 & 21,53 & & 17,57 & \\
\hline & 25 & 38,49 & & 45,05 & $32,73 \mathrm{ppm}$ \\
\hline & 50 & 93,81 & & 85,89 & \\
\hline & 100 & 94,06 & & 94,93 & \\
\hline \multirow{5}{*}{ Rimpang } & 5 & 9,28 & \multirow{5}{*}{$48,33 \mathrm{ppm}$} & 19,18 & \\
\hline & 10 & 14,48 & & 41,46 & \\
\hline & 25 & 27,85 & & 64,73 & $20,42 \mathrm{ppm}$ \\
\hline & 50 & 56,93 & & 88,37 & \\
\hline & 100 & 89,73 & & 92,45 & \\
\hline \multirow{5}{*}{ Batang } & 5 & 5,94 & \multirow{5}{*}{$42,56 \mathrm{ppm}$} & 5,57 & \\
\hline & 10 & 9,78 & & 13,74 & \\
\hline & 25 & 35,52 & & 46,16 & $37,11 \mathrm{ppm}$ \\
\hline & 50 & 69,80 & & 76,73 & \\
\hline & 100 & 92,70 & & 93,56 & \\
\hline \multirow{5}{*}{ Daun } & 5 & 5,69 & \multirow{5}{*}{$45,94 \mathrm{ppm}$} & 12,99 & \\
\hline & 10 & 16,21 & & 13,24 & \\
\hline & 25 & 32,67 & & 30,94 & $47,17 \mathrm{ppm}$ \\
\hline & 50 & 63,49 & & 69,80 & \\
\hline & 100 & 89,11 & & 82,67 & \\
\hline \multirow{5}{*}{$\begin{array}{l}\text { Vitamin C } \\
\text { (dalam metanol) }\end{array}$} & 3 & 31,68 & \multirow{5}{*}{ 3,99 ppm } & & \\
\hline & 6 & 74,26 & & & \\
\hline & 9 & 94,93 & & & \\
\hline & 12 & 96,16 & & & \\
\hline & 15 & 96,29 & & & \\
\hline
\end{tabular}


Penelitian tentang tanaman yang biasa digunakan sebagai bumbu masakan pada beberapa tahun ini lebih difokuskan untuk mengetahui kemampuannya di bidang kesehatan meliputi antioksidan, antimutagenik, dan antikarsinogenik. Hal ini karena tanaman tersebut, salah satunya kunyit, dapat melindungi tubuh manusia terhadap reaksi oksidasi seluler, infeksi bakteri, dan kelainan yang menyangkut metabolisme tubuh (Panpatil et al., 2013).

Metode perendaman senyawa DPPH merupakan pengujian yang mudah, cepat dan dapat dipertanggungjawabkan untuk menguji aktivitas antioksidan (Suhaj, 2006). Senyawa antioksidan yang ada kemudian merombak senyawa radikal dengan cara memberikan atom hidrogen atau elektron dan menangkap senyawa radikal bebas sehingga terbentuk senyawa non radikal (Stoilova et al., 2007). Akibat aktivitas tersebut, senyawa DPPH yang berwarna ungu akan dirombak menjadi senyawa $\alpha, \alpha$-diphenyl- $\beta$-picrylhydrazyl yang berwarna kuning (Akowuah et al., 2005). Seluruh ekstrak etanol dan atilasetat bagian tanaman kunyit mempunyai aktivitas antioksidan yang tergolong kuat. Hal ini memperkuat sekaligus memperluas cakupan penelitian sebelumnya yang masih terbatas pada ekstrak rimpang dan daun kunyit yang memiliki aktivitas antioksidan dan penghambatan tyrosinase (Chan et al., 2008).

Rimpang tanaman kunyit merupakan bagian yang sering digunakan dalam pengobatan tradisional di masyarakat. Tanaman menghasilkan senyawa antioksidan dalam jumlah yang besar seperti karotenoid, flavonoid, asam benzoat, asam askorbat, tokoferol untuk mencegah terjadinya oksidasi substrat (Samsudin \& Panigoro, 2013). Mengkonsumsi tanaman rempah termasuk kunyit akan berdampak baik dalam usaha pencegahan beberapa penyakit kronis seperti penyakit kardiovaskular, kanker, dan inflamasi (Hossain et al., 2008).

Penelitian tentang tanaman kunyit sebagai antimikroba dan antioksidan cenderung menggunakan minyak atsirinya (Negi et al., 1999; Naz et al., 2010; Antunes et al., 2012). Akan tetapi beberapa minyak atsiri yang beredar di pasaran ternyata hanya memiliki aktivitas antioksidan saja seperti yang telah dilaporkan oleh Antunes et al. (2012). Lebih lanjut, dalam penelitian tersebut aktivitas antimikroba didapatkan setelah penambahan asam askorbat. Oleh karena itu penelitian ini mempunyai keunggulan karena ekstrak etil asetat dan etanol seluruh bagian tanaman kunyit memiliki aktivitas antioksidan dan antimikroba sekaligus.

\section{Uji Penapisan Fitokimia}

Hasil penapisan fitokimia yang dilakukan, ekstrak etanol dan etil asetat daun tidak menunjukkan adanya senyawa flavonoid (Tabel 4). Flavonoid terdeteksi pada ekstrak etanol maupun etil asetat akar, rimpang, dan batang, namun tidak ada pada daun. Alkaloid tidak terdeteksi pada semua sampel, sedangkan steroid/triterpenoid terdeteksi pada semua sampel. Hasil uji penapisan fitokimia menunjukkan secara keseluruhan bahwa ekstrak etanol dan etil asetat masing-masing bagian tanaman kunyit megandung senyawa kimia golongan flavonoid dan steroid/triterpenoid.

Hasil penapisan fitokimia yang dilakukan, ekstrak etanol dan etil asetat daun tidak menunjukkan adanya senyawa flavonoid. Oleh karena itu pada ekstrak etanol maupun etil asetat daun kunyit mempunyai aktivitas antioksidan yang paling rendah diantara ekstrak lainnya. Hal ini karena flavonoid mempunyai aktivitas antioksidan yang tinggi (Ghasemzadeh et al., 2012). Namun demikian, penelitian ini masih sejalan dengan penelitian sebelumnya yang melaporkan bahwa ekstrak etanol daun kunyit memiliki aktivitas antioksidan (Arutselvi et al., 2012). Flavonoid golongan kaempferol dan rutin dalam tanaman kunyit mempuyai aktivitas antioksidan (Ghasemzadeh et al., 2012). Kandungan flavonoid dalam kunyit juga mampu menghambat pertumbuhan bakteri $S$. aureus, E. coli dan Klebsiella sp. (Chhetri et al. 2008). Golongan steroid dan terpenoid dalam ekstrak etanol rimpang kunyit mampu menghambat pertumbuhan bakteri $S$. aureus 
dan Enterobacter faecalis (Viji et al., 2013). Steroid/triterpenoid juga terdeteksi pada sampel rimpang kunyit yang mempunyai aktivitas antioksidan tinggi (Samsudin \& Panigoro, 2013).

Tabel 4. Penapisan fitokimia ekstrak simplisia akar, rimpang, batang dan daun kunyit

\begin{tabular}{lcccccc}
\hline \multicolumn{1}{c}{ Simplisia bagian } & \multicolumn{2}{c}{ flavonoid } & \multicolumn{2}{c}{ Alkaloid } & \multicolumn{2}{c}{ Steroid/ triterpenoid } \\
\cline { 2 - 7 } \multicolumn{1}{c}{ tanaman kunyit } & etanol & etil asetat & etanol & etil asetat & etanol & etil asetat \\
\hline Akar & + & + & - & - & + & + \\
Rimpang & + & + & - & - & + & + \\
Batang & + & + & - & - & + & + \\
Daun & - & - & - & - & + & + \\
\hline
\end{tabular}

Keterangan: (+) terdeteksi; (-) tidak terdeteksi

Adanya kandungan beberapa senyawa kimia dalam ekstrak kasar mengakibatkan senyawa kimia tersebut dapat memliki mekanisme yang beragam dalam menghambat pertumbuhan mikroba. Senyawa kimia dalam kunyit dapat juga menyerang bakteri uji dengan cara perusakan dinding sel, membran sitoplasma, protein, kebocoran sel, dan penggumpalan sitoplasma (Burt, 2004). Sedangkan senyawa kimia dalam ekstrak kasar kunyit mempunyai beberapa kemungkinan mekanisme penghambatan pertumbuhan fungi. Beberapa diantaranya ialah dengan merusak morfologi hifa yang dapat menyebabkan kerusakan sel, perusakan dinding sel, membran plasma, mitokondria, kebocoran sitoplasma, dan pelipatan membran inti (Rasooli et al., 2005).

Adanya aktivitas antimikroba dan antioksidan ekstrak etanol dan etil asetat akar, rimpang, batang, dan daun kunyit diharapkan lebih banyak lagi penelitian untuk mengeksplorasi seluruh bagian tanaman kunyit selain rimpang. Sehingga akan lebih banyak lagi manfaat yang dapat diambil dari seluruh bagian tanaman kunyit selain rimpang untuk digunakan sebagai sumber bahan obat alami maupun manfaat lainnya.

\section{SIMPULAN DAN SARAN Simpulan}

Ekstrak etanol dan etil asetat daun, batang, rimpang dan akar tanaman kunyit mempunyai aktivitas antimikroba dan antioksidan. Aktivitas antimikroba tertinggi terdapat pada ekstrak etil asetat daun dan batang terhadap $S$. aureus, ekstrak etil asetat batang dan akar terhadap E. coli, dan ekstrak etil asetat daun terhadap $C$. albicans. Sedangkan aktivitas antioksidan terbaik ialah ekstrak etil asetat rimpang kunyit.

\section{Saran}

Perlu dilakukan penelitian lebih lanjut tentang potensi ekstrak air yang lebih aman dan murah untuk dikembangkan dalam skala industri serta kajian mendalam tentang mekanisme kerja antimikroba dan antioksidan.

\section{DAFTAR PUSTAKA}

Akowuah, G.A, Ismail, Z., Norhayati, I. and Sadikun, A. 2005. The effects of different extraction solventas of varying polarities of polyphenols of Orthosiphon stamineus and evaluation of the free radicalscavenging activity. Food Chemistry. 93 (2): 311-317.

Antunes, S.A., Robazza, W.S., Schittler, L. and Gomes, G.A. 2012. Synergistic and antimicrobial properties of commercial turmeric (Curcuma longa) essential oil against pathogenic bacteria. Ciencia $e$ Tecnologia de Alimentos. 32 (3): 525530.

Arutselvi, R., Balasaravanan, T., Ponmurugan, P., Saranji, N.M. and Suresh, P. 2012. Phytochemical screening and comparative study of antimicrobial activity of leaves and rhizomes of turmeric varieties. Asian 
Journal of Plant Science and Research. 2 (2): 212-219.

Asimi, O.A., Sahu, N.P. and Pal, A.K. 2013. Antioxidant activity and antimicrobial property of some Indian spices. International Journal of Scientific and Research Publications. 3 (3): 1-8.

Baydar, H., Sagdic, O., Ozkan, G. and Karadogan, T. 2004. Antibacterial activity and composition of essential oil from Origanam, Thymbra and Satureja species with commercial importance in Turkey. Food Control. 15 (3): 169-172.

Burt, S. 2004. Essential oils: their antibacterial properties and potential applications in foods-a review. International Journal of Food Microbiology. 94 (3): 223-253.

Chan, E.W.C., Lim, Y.Y., Wong, L.F., Lianto, F.S., Wong, S.K., Lim, K.K., Joe, C.E. and Lim, T.Y. 2008. Antioxidant and tyrosinase inhibition properties of leaves and rhizome of ginger species. Food Chemistry. 109 (3): 477-483.

Chhetri, H.P., Yogol, N.S., Sherchan, J., Anupa, K.C., Mansoor, S. and Thapa, P. 2008. Phytochemical and antimicrobial evaluations of some medicinal plants of Nepal. Khatmandu University Journal of Science, Engineering and Technology. 1 (5): 49-54.

Fransworth, N.R. 1966. Biological and phytochemical screening of plants. Journal of Pharmaceutical Science. 55 (3): 225-276.

Fratianni, F., Nazzaro, F., Marandino, A., Fusco, M.R., Coppola, R., De Feo, V. and De Martino, L. 2013.Biochemical composition, antimicrobial activities, and anti-quorum-sensing activities of ethanol and ethyl acetate extracts from Hypericum connatum Lam. (Guttiferae). Journal of Medical Food. 16 (5): 454-459.

Ghasemzadeh, A., Azarifar, M., Soroodi, O. and Jaafar, H.Z.E. 2012. Flavonoid compounds and their antioxidant activity in extract of some tropical plants. Journal of Medicinal Plants Research. 6 (13): 2639-2643.

Hanouda, T. and Baker, J.R. 2000. Antimicrobial mechanism of action of surfactant lipid preparation in enteric gram negative bacilli. Journal of Applied Microbiology. 89 (3): 397403.

Hossain, M.B., Brunton, N.P., Barry-Ryan, C., Martin-Diana, A.B. and Wilkinson, M. 2008. Antioxidant activity of spices extracts and phenolics in comparison to synthetic antioxidants. Rasayan Journal of Chemistry. 1 (4): 751-756.

Lambert, R.J.W., Skandamis, P.N., Coote, P.J. and Nychas, G.J.E. 2001. A study of the minimum inhibitory concentration and mode of action of oregano essential oil, thymol and carvacrol. Journal of Applied Microbiology. 91 (3): 453-462.

Lis-Balcin, M. and Deans, S.G. 1997. Bioactivity of selected plant essential oils againts Listeria monocytogenes. Journal of Application Microbiology. 82 (6): 759-762

Mazumder R, Mediratta T, Mondal SC and Mazumder A. 2000. Antimicrobial potency of the leaf-stalk extract of Curcuma longa (LINN). Ancient Science of Life. 20 (1-2): 92-96.

Nahak, G. and Sahu, R.K. 2011. Evaluation of antioxidant activity in ethanolic extracts of five curcuma species. International Research Journal of Pharmacy. 2 (12): 243-248.

Naz, S., Jabeen, S., Ilyas, S., Manzoor, F., Aslam, F. and Ali, A. 2010. Antibacterial activity of Curcuma longa varieties against different strains of bacteria. Pakistan Journal of Botany. 42 (1): 455-462.

Negi, P.S., Jayaprakasha, G.K., Rao, L.J.M. and Sakariah, K.K. 1999. Antibacterial activity of turmeric oil: a by product from curcumin manufacture. Journal of Agricultural 
and Food Chemistry. 47 (10): 4297 4300.

Panpatil, V.V., Tattari, S., Kota, N., Ningulkar, C. and Polasa, K. 2013. In vitro evaluation on antioxidant and antimicrobial activity of spice extracts of ginger, turmeric and garlic. Journal of Pharmacognosy and Phytochemistry. 2 (3): 143-148.

Parveen, Z., Nawaz, S., Siddique, S. and Shahzad, K. 2013. Composition and antimicrobial activity of the essential oil from leaves of Curcuma longa $\mathrm{L}$. kasur variety. Indian Journal of Pharmaceutical Sciences. 75 (1): 117-122.

Pattaratanawadee, E., Rachtanapun, C., Wanchaitanawong, P. and Mahakarnchanakul. 2006. Antimicrobial activity of spice extracts against pathogenic and spoilage microorganisms. Kasetsart Journal: Natural Science. 40 (5): 159-165.

Rasooli, I., Rezaei, M.B. and Allameh, A. 2006. Growth inhibition and morphological alterations of Aspergillus niger by essential oils from Thymus eriocalyx and Thymus x-porlock. Food Control. 17 (5): 359364.

Samsudin, S. and Panigoro, R. 2013. Comparison of antioxidant activity between decoction of dried Curcuma longa L., and Curcuma xanthorrhiza Roxb. rhizomes. International Journal of Research in Phytochemistry Pharmacology. 3 (1): 27-30.

Schelz, Z., Hohmann, J. and Molnar, J. 2010. Recent advances in research of antimicrobial effects of essential oils and plant derived compounds on bacteria. Ethnomedicine: A source of complementary therapeutics (ed. Chattopadhyay D). 179-201.

Stoilova, I., Krastanov, A., Stoyanova, A., Denev, P. and Gargova, S. 2007. Antioxidant activity of a ginger extracts (Zingiber officinale). Food Chemistry. 102 (3): 764-770.

Suhaj, M. 2006. Spice antioxidants isolation and their antiradical activity: a review. Journal of Food Composition and Analysis. 19 (6-7): 531-537.

Sunilson, J.A.J., Suraj, R., Rejitha, G., Anandarajagopal, K., Kumari, A.V.A.G. and Promwichit, P. 2009. In vitro antimicrobial evaluation of Zingiber officinale, Curcuma longa and Alpinia galanga extracts as natural food preservatives. American Journal of Food Technology. 4 (5): 192-200.

Tiwari, V., Shanker, R., Srivastava, J. and Vanker, P.S. 2006. Change in antioxidant activity of spices-turmeric and ginger on heat treatment. Electronic Journal of Environmental, Agriculture and Food Chemistry. 5 (2): 1313-1317.

Viji, G.S., Vasanthe, B. and Saresh, K. 2013. Screening and antibacterial activity analysis of some important medicinal plants. International Journal of Innovation and Applied Studies. 2 (2): 146-152.

Yan, S.W. and Asmah, R. 2010. Comparison of total phenolic contents and antioxidant activities of turmeric leaf, pandan leaf and torch ginger flower. International Food Research Journal. 17 (2): 411-423. 